\title{
EVALUATING SUSTAINABLE COMMUNITY-BASED FOREST MANAGEMENT: A REFLECTION ON NEPAL'S EXPERIENCES WITH THE ANALYTIC HIERARCHY PROCESS
}

\author{
Chiranjeewee Khadka* \\ University of Natural Resources and Life Sciences \\ Department of Forest and Soil Sciences, Institute of Silviculture \\ PeterJordan Strasse 82, A-1190, Vienna, Austria \\ Email: chiranjeewee.khadka@boku.ac.at \\ Harald Vacik \\ University of Natural Resources and Life Sciences \\ Department of Forest and Soil Sciences, Institute of Silviculture \\ PeterJordan Strasse 82, A-1190, Vienna, Austria \\ Email: harald.vacik@ boku.ac.at
}

\begin{abstract}
Sustainable forest management (SFM) usually involves the use of criteria and indicators (C\&I) because they allow the monitoring, reporting and assessment of management activities at national, regional and forest management unit levels. Experiences with such concepts are scare in Nepal - particularly regarding the evaluation of C\&I management activities within community forest management (CFM). The Analytic Hierarchy Process (AHP) is used in this contribution to examine the importance of C\&I in participatory decision-making processes with a broad range of stakeholder groups. It shall be shown that the AHP is especially suited for multi-criteria decision problems with a high number of diverse indicators and stakeholder interests. The paper focuses on the evaluation of four management strategies in the Shree Gyneshwar community forest user group, Nepal. An AHP model is used to derive the priorities of six criteria and forty-four indicators, and finally to select the best management strategy. The assessment of C\&I priorities from different stakeholder perspectives provides an opportunity for the analysis of different scenarios. The results of this study show that the MCA approach utilizing the AHP can assist decision makers in effectively evaluating management problems and generating ideas for the long-term strategic planning process of CFM. In that context, compromise solutions enjoy a higher possibility of being successful, taking into account the different views of stakeholder groups. The sensitivity analysis applied can therefore not only be used to assess the robustness of the evaluation, but also to appraise the influence of each criterion in the selection of the best alternatives.
\end{abstract}

Keywords: Multiple-criteria decision problems, AHP, criteria and indicators, community forestry, Nepal.

\section{Introduction}

The involvement of stakeholders to manage the forests as community forestry in Nepal has become a widely accepted participatory management philosophy along with the sustainability concept. Community

\footnotetext{
${ }^{*}$ Corresponding author
} 
forestry can be described as laboratory for participatory resource management where collaboration and co-ordination between and among all stakeholders is practiced day by day (Khadka and Vacik 2008). In managing natural resources decision problems involving multiple criteria or attributes, the decision criteria should be prioritized and grouped in a collaborative manner in order to organize information and allow judgments about a preferred alternative. The existing collaborative planning approaches in community forest management in Nepal are not utilizing Multiple Criteria Analysis (MCA) for evaluating forest management. Although Hjortso et al. (2006) applied Multiple-Objective Programming and Goal Programming for a land use planning case in the protected area-buffer zone management of the Chitwan National Park; they failed to analyze the decision problem in a collaborative manner. However, a number of applications evaluating forest management with MCA techniques describe their limitation for practical use in the course of implementation (Mendoza and Prabhu 2000a, 2005; Herath 2004; Wolfslehner et al. 2005).

The AHP has been applied to elicit preferences in a vast range of natural resource policy areas (Schmoldt et al. 2001; Mardle et al. 2004) and multi-objective forest management problems (Vacik and Lexer 2001, Vacik et al. 2007). As the concept of C\&I has emerged in an increasing number of initiatives at global, national and forest management unit level it has been applied in community forest management in Nepal as well (Khadka and Vacik, forthcoming). Drawing on the experiences of a C\&I development project in Nepal, this study meant to evaluate the overall performance of forest management options by the use of the AHP and perform a sensitivity analysis to identify an overall compromise solution in the case study area for supporting community forest management in Nepal.

\section{Shree Gyneshwar Community Forest Management}

Shree Gyneshwar Community Forest (SGCF) is located at Mangalpur Village Development Committee (VDC), Chitwan district of central region development, Nepal. It has an area of 208 hectare and 2300 Households (HHs) inhabitants (2009). Due to human settlements, increasing fuelwood demands, population pressures, and conversation of forest land to agriculture land and illegal practices, the forest was totally naked in the period of 1980s. The Timber Corporation of Nepal (TCN) initiated a plantation program with Dalbergia Sissoo (Sissoo) in this area in 1981 and handed over the plantation areas to the District Forest Office (DFO), Chitwan. The government local authorities adapted the traditional participatory approaches with the consultation of local users and formed the constitution and operational plan with an ad-hoc committee without specifying objectives and activities and handed over the forests in 2001. CFUG initiated collaborative planning to develop a vision, goals, planning, self-monitoring processes and aimed to utilize MCA approaches including the AHP. The MCA approach focused mainly on four phases: awareness building, criteria and indicators developments, elicitation of preferences and analysis and implementation of management strategies.

\section{Results}

\subsection{Elicitation of preference for C\&I of SFM}

The awareness building phase intended to share the results of studies on i.e. socio-economic, institutional, historical, policy and bio-physical background of a case study site. In the C\&I development phase the participants discussed the main principles of SFM and came to a shared vision. Before conducting the C\&I development workshop, the research team and local facilitators organized 20 tole/hamlet level meetings to derive the opinions and experiences from all stakeholder groups. In the C\&I development workshop a 71 users into 12 groups from advisory groups, executive members, general users and local facilitators developed and assessed finally a set of six criteria and 44 indicators (for more details please refer to Khadka and Vacik, forthcoming). Ranking, ratings and pairwise comparison techniques which are commonly used in C\&I assessment studies (see, Schmoldt et al. 2001, Ramanathan, 2001; Vacik et al. 2001) have been applied. In this study, for the rating a score between 0 and 9 was assigned and the ranks were assigned following a nine-point scale (depending on the number of indicators related to criteria). 
Pairwise comparisons were done by the local facilitators based on the input (ranking, rating) provided by the stakeholder groups according to each single indicator and the priorities where calculated using the eigenvalue method of the Expert Choice software.

The result obtained from the rating ( $0-9$ scale), ranking and the geometric mean of the priorities derived from the 12 stakeholder groups for the criteria level is presented in Table 1. Criterion 3 (i.e., encourage multiple forest products and services and a wider range of environmental and forest health) was ranked as the most important criterion for sustainable community forest management. The small variability of the individual preferences $(\mathrm{sdv}$. of rating $=0.49)$ reflect a high consistency among the twelve stakeholder groups.

Table 1: Preferences of criteria based on rating, ranking and Pairwise comparisons (PWC) methods (n=12)

\begin{tabular}{llllll}
\hline Criteria & $\begin{array}{l}\text { Arith. mean } \\
\text { rating (0-9) }\end{array}$ & $\begin{array}{l}\text { sdv. of } \\
\text { rating }\end{array}$ & $\begin{array}{l}\text { Arith. mean } \\
\text { ranking (1-n) }\end{array}$ & $\begin{array}{l}\text { sdv. of } \\
\text { ranking }\end{array}$ & $\begin{array}{l}\text { Gmean of } \\
\text { priorities (PWC) }\end{array}$ \\
\hline $\begin{array}{l}\text { C1: Compliance all international, national and } \\
\text { local laws under policy framework }\end{array}$ & 6.5 & 1.09 & 4.00 & 2.26 & 0.1175 \\
$\begin{array}{l}\text { C2: Silvicultural practices and other } \\
\text { management system }\end{array}$ & 7.58 & 1.08 & 2.33 & 1.78 & 0.1799 \\
$\begin{array}{l}\text { C3: Encourage multiple forest products and } \\
\text { services and a wide range of Environmental } \\
\text { and Forest health }\end{array}$ & 7.67 & 0.49 & 1.67 & 0.78 & 0.1919 \\
$\begin{array}{l}\text { C4: Appropriate enhancement of management } \\
\text { plan }\end{array}$ & 7.25 & 1.6 & 2.17 & 1.70 & 0.1080 \\
$\begin{array}{l}\text { C5: Long-term social and economic well-being } \\
\text { of local communities under community }\end{array}$ & 6.08 & 1.08 & 4.58 & 1.00 & 0.1903 \\
$\begin{array}{l}\text { relations } \\
\text { C6: Regular monitoring and assessment }\end{array}$ & 7.17 & 1.11 & 2.33 & & \\
\hline
\end{tabular}

\subsection{Formulating forest management options}

Based on the experiences gained from the preference elicitation workshops the CFUG developed site specific objectives and management strategies to improve of the livelihood of the poor and promote social inclusion. Four management strategies were defined in a participatory way in order to evaluate, compare and select the most preferred forest management option that serves community forest management at its best.

- Management Strategy 1(MS I): presents a traditional participatory approach by focusing on protection measures (e.g. zero grazing, making fire lines, patrolling by forest guards, no harvesting) and avoiding any active management. This strategy was postulated by traditional users, old committee and elite members.

- Management Strategy 2 (MS II): presents a participatory approach and also supports the protection management regime, purposed by main position holders of executive committee members.

- Management Strategy 3 (MS III: presents the adaptive collaborative planning approaches and introduce production management system and supports the approaches of inclusions especially in institutional arrangements, This strategy was purposed by executive members and tole representatives.

- Management Strategy 4 (MS IV): presents the adaptive collaborative planning approaches and extremist views for active forest management systems and advocating for new institutional arrangements, purposed by local facilitators dominating of youth members. 


\subsection{Evaluation of management strategies}

All 71 users formed 12 sub-groups (according to the four stakeholder groups) did a qualitative assessment regarding the performance of all management strategies against each indicator. The stakeholders tried to assess if the management strategy would allow no change or a positive improvement in comparison with the current situation. The qualitative evaluation was highly dependent of the perception of stakeholder groups and related to the available information of the management strategies and results from the context studies (e.g. constitution and operational plan). Based on their preferences, an evaluation hierarchy (Fig 1) was set up with 6 Criteria and 44 indicators using the Analytical Hierarchy Process (AHP). Pair-wise comparisons have been used to evaluate the performance of all management strategies according to each single indicator using the qualitative assessment as input.

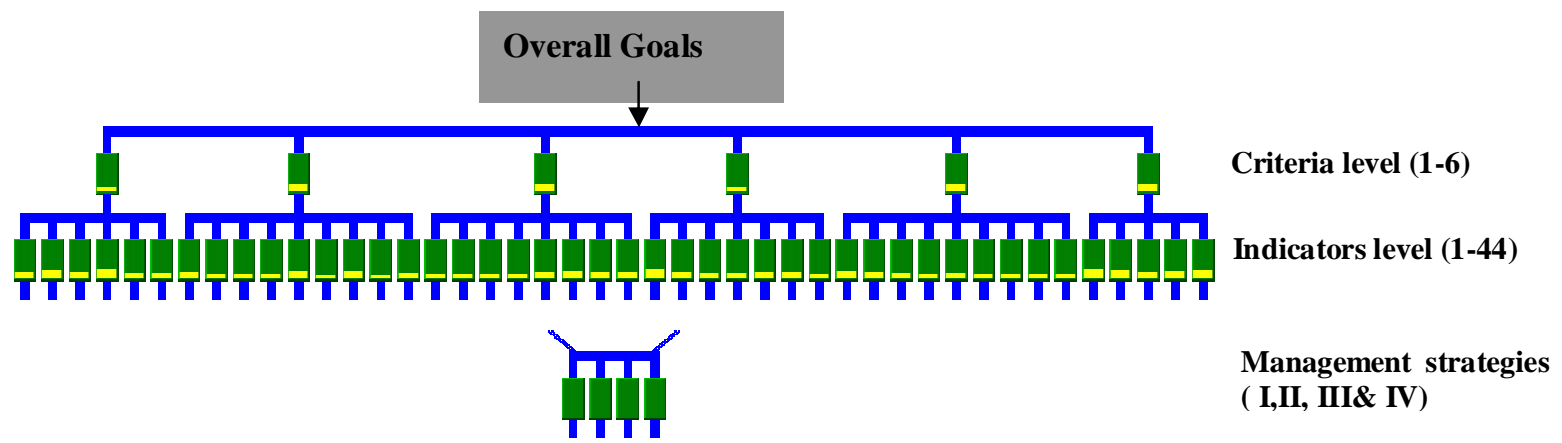

Figure 1: Analytical Hierarchical Process (AHP) model for the evaluation of management strategies according to C\&I set

The priorities and rank of the four management strategies based on the geometric mean of the synthesized judgments with respect to the stakeholder groups is shown in Table 2. For the Advisory and Committee members groups, MS III and MSIV are ranked first and second, for the General members and local facilitators groups, MS IV and MSIII are ranked first and second, respectfully. In considering the priority of all stakeholder groups it was found that MSIII is the best alternative management options, but in general MS III and MSIV are very close.

Table 2: Priorities of management strategies based on geometric mean of the synthesized judgment with respect to the stakeholder groups

\begin{tabular}{|c|c|c|c|c|c|c|c|c|c|c|}
\hline \multirow[t]{2}{*}{$\begin{array}{l}\text { Management } \\
\text { strategies }\end{array}$} & \multicolumn{2}{|c|}{$\begin{array}{l}\text { Advisory } \\
\text { members }\end{array}$} & \multicolumn{2}{|c|}{$\begin{array}{l}\text { Committee } \\
\text { members }\end{array}$} & \multicolumn{2}{|c|}{$\begin{array}{l}\text { General } \\
\text { members }\end{array}$} & \multicolumn{2}{|c|}{$\begin{array}{l}\text { Local } \\
\text { facilitators }\end{array}$} & \multicolumn{2}{|c|}{$\begin{array}{l}\text { All } \\
\text { stakeholders }\end{array}$} \\
\hline & Priority & Rank & Priority & Rank & Priority & Rank & Priority & Rank & Priority & Rank \\
\hline MSI & 0.182 & 4 & 0.157 & 4 & 0.139 & 4 & 0.138 & 4 & 0.157 & 4 \\
\hline MSII & 0.192 & 3 & 0.178 & 3 & 0.175 & 3 & 0.172 & 3 & 0.181 & 3 \\
\hline MSIII & 0.317 & 1 & 0.334 & 1 & 0.342 & 2 & 0.340 & 2 & 0.332 & 1 \\
\hline MSIV & 0.309 & 2 & 0.331 & 2 & 0.345 & 1 & 0.350 & 1 & 0.330 & 2 \\
\hline
\end{tabular}

\subsection{Sensitivity analysis of management strategies}

Sensitivity analysis on the effect of changes in local priorities provides useful insights into the stakeholder preference (Ananda 2007). Fig 2 shows the response of the management strategies with respect to each criterion. In that respect, it was found that MS I is the best alternative option according to the Policy framework (C1), followed by MSIII, MSIV and MSII. According to the C2 (Silvicultural practices and other management system), C4 (appropriate management plan) and C6 (Regular monitoring and assessment), MSIV is the best management options and followed MSIII, MSII and MSI. The best option is MS II, if only Environmental and Forest health (C3) is considered as mainly important. MS III is the best management option, if the long-term social and economic benefit to the local users (C4) is 
considered as the priority objective. In overall, MSIII is the best management option for all stakeholder preferences whereas MSI has the least priorities for all stakeholder groups.

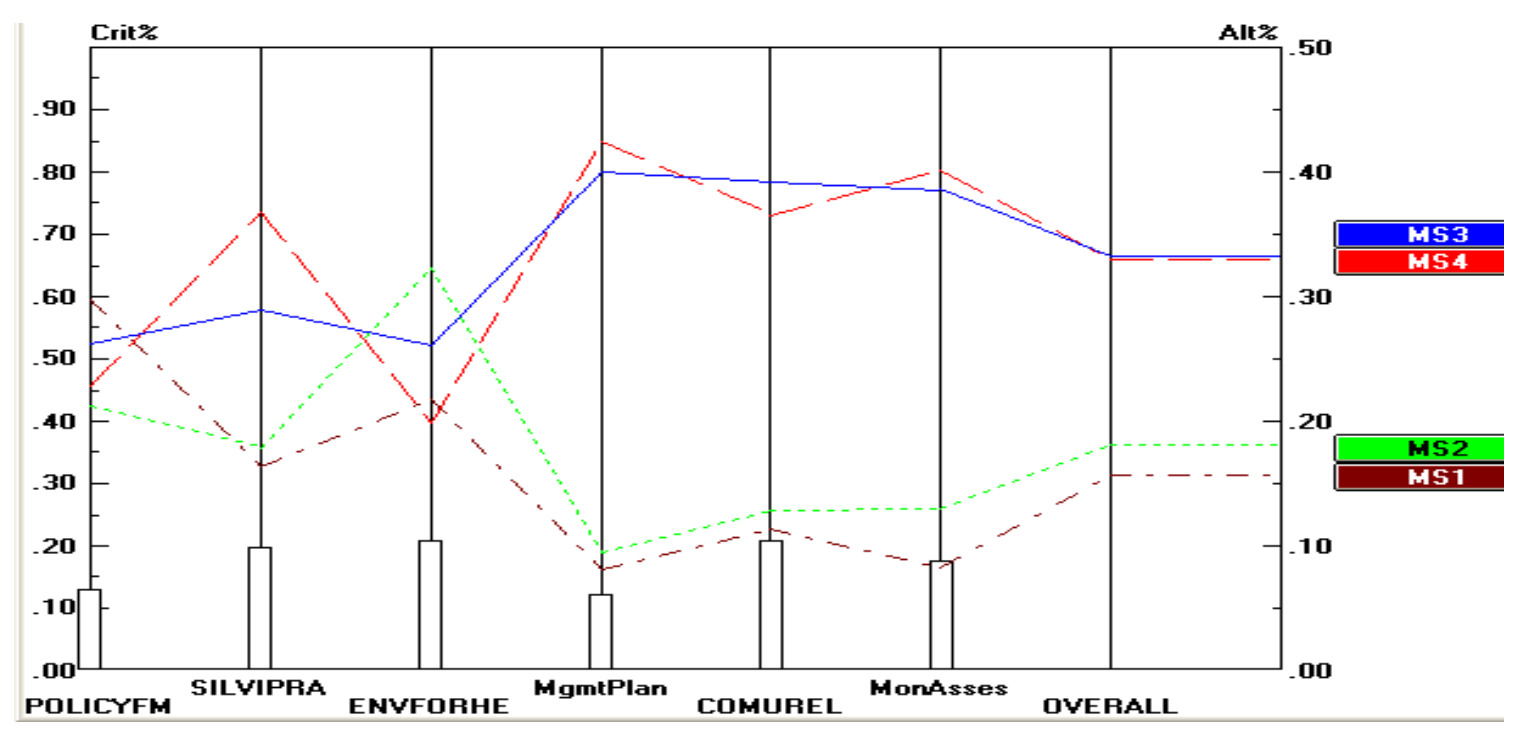

Figure 2: Sensitivity analysis of the synthesized judgment of all stakeholder groups for the management strategies according to C\&I set (Source: Screenshot from Expert-choice software)

\section{Conclusions}

The four different management approaches and the evaluation framework were derived from the identified needs and expectation of the different social-economic and institutional actors. The qualitative assessment of C\&I priorities from different stakeholder perspectives provided an opportunity for the analysis of different scenarios. The results of this study show that the multi-criteria analysis approach utilizing the AHP can assist decision makers in effectively evaluating management problems and generating ideas for the long-term strategic planning process of CFM - even under complex socioeconomic and ecological conditions. In that context, compromise solutions have higher possibilities for realization taking into account the different views of stakeholder groups. The sensitivity analysis performed can therefore be used not only to assess the robustness of the evaluation but to appraise the influence of each criterion in the selection of best alternative options. As a result of the sensitivity analysis it was found that the proposed management strategies I and II were favored by traditional users, local elites and some committee members. However, they ignored new innovations like participation, livelihood enhancement, institution improvement and active forest management. Therefore, MS III was selected as a best management strategy. The use of the AHP helped to identify the preferences of the various stakeholder groups and made their visions and goals clear. However elites and newly elected committee members paid less attention to forward the management plan to get the approval and implement the agreed management options accordingly. So this study shows that the overall decision making process of CFM could be supported by means of a C\&I approach applying the Analytic Hierarchy Process in the future but needs a strong support for facilitation and final implementation.

\section{REFERENCES}

Ananda. J. 2007. Implementing Participatory Decision Making in Forest Planning. Environ. Manage 39, $534-544$ 
Herath, G. (2004). Incorporating community objectives in improved wetland management: the use of the analytic hierarchy process. Journal of Environmental Management, 70, 263-273.

Hjorts $\varnothing$, C.N., Stræde, S., \&Helles F. (2006). Applying multi-criteria decision-making to protected areas and buffer zone management: A case study in the Royal Chitwan National Park, Nepal Journal of Forest Economics, 12, 91-108.

Khadka C., \& Vacik H. (2008): Applying Adaptive collaborative management for social learning: A case study of community forestry in Nepal. In: Maurer et al. [Eds.], Proceedings of I-Know 08 and I-Media 08 - International Conferences on Knowledge Management and New Media Technology, Journal of Universal Computer Science (J.UCS), p. $101-108$.

Khadka and Vacik, (forthcoming): Comparing a top-down and bottom-up approach in the identification of criteria and indicators for sustainable Community Forest Management - A case study of Nepal, submitted to Journal of Environmental Management.

Mardle S, Pascoe S., \& Herrero I. (2004) Management objective importance in fisheries: an evaluation using the Analytic Hierarchy Process (AHP). Environmental Management, 33, 1-11

Mendoza, G.A., Macoun, P., Prabhu, R., Sukadri, D., Purnomo, H., \& Hartanto, H. (1999). Guidelines for Applying Multi-Criteria Analysis to the Assessment of Criteria and Indicators. Center for International Forestry Research, Jakarta.

Mendoza, G.A., \& Prabhu, R. (2000a). Multiple criteria decision making approaches to assessing forest sustainability using criteria and indicators: a case study. Forest Ecol. Manag, 131, 107-126.

Ramanathan, R. (2001). A note on the use of the analytic hierarchy process for environmental impact assessment. Journal of Environmental Management 63, 27-35.

Schmoldt, D., Kangas, J., Mendoza, G. \& Pesonen, M. (2001) The Analytic Hierarchy Process in Natural Resource and Environmental Decision Making, Vol. 3 in the series Managing Forest Ecosystems, Dordrecht, Boston, London: Kluwer Academic Publishers.

Wolfslehner, B., Vacik, H., Manfred, J., \& Lexer, M.J. (2005). Application of the analytic network process in multi-criteria analysis of sustainable forest management. Forest Ecology and Management 207, $157-171$.

Vacik, H., \& Lexer M.J. (2001): Application of a spatial decision support system in managing the protection forests of Vienna for sustained yield of water resources. Forest Ecology and Management 143, $65-76$.

Vacik, H., Wolfslehner, B., Seidl, R., \& Lexer M.J (2007): Integrating the DPSIR-approach and the Analytical Network Process for the assessment of forest management strategies. In CAB. International: Sustainable Forestry: from Monitoring and Modelling to Knowledge Management and Policy Science (eds. K.M. Reyonolds, A.J. Thomson, M. Köhl, M.A. Shannon, D. Ray and K.Rennolls). 